\title{
The Fate of Psychiatry in the New Populism*
}

\author{
Petre Sedgwick, Department of Politics, University of Leeds
}

It has seemed to me and many others that Britain is now entering a political phase in which the post-war consensus around matters of social welfare is being dissolved in favour of a new set of assumptions which emphasize the individual's recourse to law or to legally-embodied appeal procedures, even at the expense of more collective rights which were previously enshrined (imperfectly, it is true, but still definitely) in State-sponsored welfare provision. As I present it here, the implication is made of a fundamental antagonism, perhaps, and more certainly of a serious and unmistakable competition, between the claims of a legally-inspired and individualistic approach and the aspirations of medicine and psychiatry which are grounded in the availability of collective provisions: collective in a double sense, as being both the product of politically organized popular demand and also the expression of structured interventions by the State and other social agencies aligned with the State. It is this dualism between medicine and law, or at a more rarefied level between an individualism founded on contractual civil relations and a collectivism rooted in the institutions of mass democracy and public spending, which I feel needs most justification in argument, and which clearly lacks such justification in the remarks I shall offer here.

With that proviso, let me outline the concerns which have brought me to the point of asking such questions about the general ideological context of debates about psychiatry. In the last chapter of my book, Psycho Politics ${ }^{1}$, I tried to sketch what I considered were some of the broad 'conditions of possibility' for the emergence of psychiatry in its post-war state and shape. By examining the record of mental hospital reform since 1945 in different European countries, I was able to show that the timing of major changes in the psychiatric health services, from the predominant in-patient treatment of the old 'asylum solution' to the replacement of asylum placement by out-patient, community treatment as the method of first choice, varied extraordinarily from one national culture to another. I suggested that it was elements in a country's national political history, and in particular its popular anti-fascist awakening and the degree to which it has developed social-insurance funding in response to mass democratic pressures, which were of particular significance in providing the contextual pre-conditions for the growth of a liberalized psychiatry.

While I think that the position I offered on the importance of political culture in the war-time and post-war period is still defensible, I now want to amend and develop a particular contention which I offered about our own nation's record of political and psychiatric health. In a schematic way I sub"This article is based on a paper presented at the Annual Meeting of the College in London on 8 July 1982. divided the British history of psychiatric care and aftercare since the 40s into two phases: a relatively progressive, innovatory and integrated period of burgeoning social psychiatry, symbolized in the hey-day of 'therapeutic community' experiments, extending from beginnings in war-time into the early 60 s, with some obvious continuations into our own time; and overlapping with this first epoch of relative progress, but later overtaking it, a successor phase of the dilapidation of long-term provision for the mentally ill and a reduction of therapeutic goals from social rehabilitation to symptom-relief through acute therapies. In this latter period-our own therapeutic era-the apparently emancipatory programme of abolishing the mental institution has become in practice a smokescreen of rhetoric behind which those many patients who need something more than a course of medication or ECT are dumped into a no-man's-land of scarcely existent 'community care' facilities. I even suggested that 'the field of public mental health' had become ' $a$ testing ground for the idea of monetarism and Friedmanism even before these anti-collectivist creeds became popularized as solutions for the whole of society' (p. 210).

The first governmental prophet of de-hospitalization was, of course, Mr Enoch Powell, who delivered his famous 'watertower speech' in 1961 only three years after he had resigned from the Macmillan administration for its refusal to countenance the massive cuts in public expenditure which he had canvassed as a member of the Treasury team. His successor as a Conservative demolitionist of the asylum was Sir Keith Joseph, who, in 1971, again offered the firm perspective of the evacuation of all mental hospitals in the next decade and a half. To these two examples of Tory zeal for de-hospitalization one may now add Mr Patrick Jenkin, who during his tenure of the Thatcher government's social service department offered himself as a principal apologist of the 'new voluntarism' in which the statutory services would act as the mere 'safety net, the final protection for people for whom there is no other, not as the first port of call' (to quote from his Guardian article of January 1981). In his Department's consultation paper published in 1980, the perspective was raised of closing as many as thirty mental hospitals as soon as possible, and Mr Jenkin's speech to the MIND annual conference later that year argued that 'many large hospitals will soon be redundant'-a retreat from earlier sanguine forecasts of the complete abolition of the county mental institution, but also a significant concretization of an intermediate goal in this programme.

It does seem, therefore, as if Conservative administrations have a tendency to step up and move forward policies of mental hospital abolitionism which in a more diffuse and general way are part of the policy consensus accepted by all 
parties, both political and medical. Despite the difficulties in explaining such a Tory predilection, the task of providing some account of its intellectual or other antecedents should be faced. There is an obvious temptation to seek broad cultural predispositions for a Conservative hostility to total public institutions: one recalls that the nineteenth century popular battles against the establishment of workhousesthe notorious 'Bastilles' of the post-1834 Poor Law legislation-were often led by Tory philanthropists. It is equally tempting, though doubtless too crude, to speculate on a possible economic motivation for the current trend, in that modern Conservatives are likely to be only too sensitive to the commercial value of the sites on which mental hospitals stand.

My claim in Psycho Politics of the arrival of a 'psychiatric monetarism' in British health service thinking can fairly be criticized as itself implying an excessively economic motivation for the most recent period of the shift towards community services at the expense of the mental hospital. 'Monetarism' can itself be regarded as a relatively incidental accompaniment of other and wider political strategies characteristic of the Thatcher ministry. Despite the rhetoric and the programme, no mental hospital has actually yet been closed down: and the undeniable havoc that has been wrought in community-based aftercare services during the Thatcher-Heseltine onslaught on local-authority expenditures is a reflection not merely of a fashionable Friedmanist nostrum for economic recovery but of longstanding parsimony and inadequacy in the quality as well as the quantity of provision by local councils for the disabled and poor. Nor, in the field of psychiatric delivery itself, do we witness any obvious popularity of a fee-paying, contractual model of servicing mental patients: despite the arrival, in the advertisement pages of the British Journal of Psychiatry, of the Chelsea-based 'Charter Clinic' with its offer of a gourmet cuisine and jacuzzi bathing for the well-heeled in-patient or out-patient, with a specialty in the treatment of alcoholism. It is not in the growth of a fee-paying private sector as a rival that the run-down of public mental health provision is expressed, but rather in the shifting of the burden of continuing care away from any organized medical base whatever and into the twilight zones of the lodging house, the Salvation Army hostel, the prison for the mentally ill offender and, for many sufferers, the isolated nuclear family.

While 'psychiatric monetarism' is the wrong term to cover the contemporary mental health scene in Britain, it is pretty much agreed by students of welfare policy that there has been a marked shift in the climate of opinion and organization affecting the social services since the latter Seventies, some of the commonest expressions now used in this connection being 'the mixed economy of welfare', the cultivation of the 'informal sector' of provision in contrast to the statutory sector, and the 'disengagement of the state'.'

Ever since the time of the French Revolution, psychiatry has benefited from the advance of a moderate collectivism in which the State assumed a growing responsibility for the health and well-being of the citizen. As public hospital and social-insurance provisions proliferated from the nineteenth century until the welfare dispensations of the governments which followed World War II, medically-trained personnel found niches available for their own decision-making powers at key points in the management of the public health. Indeed, a large number of mental health reformers outside the ranks of psychiatry have long complained of the complex entanglement between the professional élite of medicine and the bureaucratic hierarchy of power in the public services. Government listened to the advocacies of the psychiatric profession at the expense of other potential professions in care: often, it was claimed, at the expense of patients themselves. The question that must now be raised is this: if the state is disengaging from public welfare, including public health and (within that) public mental health, if, moreover, the tide of gradually advancing collectivism is now being rolled back through a Right-wing attack on the welfare consensus of the old Centre-what happens to the authority of publicly-employed psychiatrists, whose destinies have been historically involved with the fortunes of the Welfare State?

Many of you doubtless feel, in responding to the activities of Parliament in considering the Mental Health (Amendment) Act, that whatever Zeitgeist it may have been that supported the hegemony of psychiatry, it has become dissipated: the spirit of a new age is abroad which bids legislators to check and constrain the power of the medically qualified to adjudicate and treat in mental illness. The old romantic anti-psychiatry of the Laingians and their intellectual kin may have passed its prime (not least through the mellowing of Laing himself into a distinctly 'medical' stance); but there is emerging a much more conservative anti-psychiatry whose motivations, as I will briefly argue, accord well with some populist political themes that are partly the prerogative of the Tory Right, but which are being picked up by politicians from other parties. Legalistic antipsychiatry is feeding on a mood of public scepticism towards psychiatric expertise which is exemplified in the general satisfaction at the outcome of the Sutcliffe trial last year at the Old Bailey, and at the Appeal Court this year, where the diagnosis of the defendant was performed against the indications of medical evidence (presented poorly, it is true), first by a jury and then by a panel of judges utterly ignorant of psychiatry.

But to revert to Parliament's own continuing arbitration of the proper role of psychiatrists in the debates around the Mental Health (Amendment) Act: it has been notable to see that the psychiatric profession now lacks any source of stable advocacy from any quarter whatever in either House. Not only the National Office of MIND but the British Association of Social Workers has been able to command a consistently respectful hearing in the drafting and further amendment of the Act, of the sort that has proven impossible to muster on behalf of this College and its allies in, for 
example, the relatives of the National Schizophrenia Fellowship. How are we to describe, let alone to explain, the ethos of suspicion towards psychiatric medicine which has governed the drafting of the Act and its various emendations during the legislative process? Have we here a simple swing of the pendulum back from permissiveness in relation to medical authority towards a civil-libertarian zeal for 'patients' rights'? It is a more complex scenario which is now unfolding: we cannot seriously regard as committed civillibertarians some of the MPs who have volunteered to go on the Select Standing Committee which has been working its way through the Act: who have indeed been particularly vocal in anti-psychiatric amendment during the recent stage of the Act's drafting. Let us dwell for a moment on the general political stance of $\mathrm{Mr}$ Harvey Proctor and $\mathrm{Mr}$ Michael Brotherton, two Conservative MPs of the maverick far Right who have been such eager tribunes of individual liberty on the Standing Select Committee: is their concern for the rights of the citizen a consistent one, or one directed selectively towards psychiatric issues? Rather selective, in my view, with a selectiveness that needs some explaining: I note from the January 1982 issues of Searchlight, an antifascist and anti-racist information bulletin, that both $\mathrm{Mr}$ Proctor and $\mathrm{Mr}$ Brotherton have been conspicuous in meetings of the racist society WISE (Welsh Irish Scots English) which unites Right-wing nationalists with outright fascists and nazis. In July 1981 Mr Proctor addressed WISE on one of his cherished topics, repatriation, and his vote of thanks was proposed by a leading figure in one of the National Front splinter-groups.

From a non-fascist, but still Right-wing and authoritarianpopulist position, The Rev. Martin Smyth, a Commons MP who sits as the delegate of Orange domination from a North Irish constituency, was also active on the Special Standing Committee: hardly a representative of any consistent libertarianism on active civic-freedom questions.

Now, of course, there is nothing to stop a Member of Parliament, or for that matter any ordinary citizen, from being highly authoritarian one week, to the point of consorting with fascists and with fascist politics, and distinctly libertarian in another, unrelated field the next week. One is however tempted to wonder whether Right-wingers of the ilk of $\mathrm{Mr}$ Brotherton and Mr Proctor have acquired some vested interest of their own in producing checks and safeguards against psychiatric powers, since they are so often lumped in with 'the lunatic fringe'. It is impossible simply to dismiss each and every proposal proceeding from politicians with a murky general background. In any case the libertarian energies of Messrs Brotherton and Proctor are seconded ably on the Committee by figures with quite a different political orientation: Mr Christopher Price, for instance, a foremost New Statesman contributor and former PPS to Anthony Crosland, and $\mathrm{Mr}$ Mike Thomas, one of the pioneering mould-breakers of the Social Democratic Party. And the general tendency of the Act, with its limitations upon psychiatric decision-making, comes of course not from mavericks or backbenchers but from the Government and the Department of Health itself.

The phenomenon surely attests to the success of a populism directed against a focus of authority which is easily targeted and which can be combated without raising any of the vexed questions of resource-distribution, in both the amount and the direction of public spending, where the parties are both disunited and, in the main, incapable of offering very much. Indeed, for some politicians, attacking the coercive retention of mental patients in hospitals might chime in with an emphasis on reductions in public expenditure, since there would be that many fewer patients to house, feed and treat. Correspondingly, it would be awkward for these leaders of opinion to turn their fire on the failure by hospitals and social services to admit and retain those psychiatric casualties who at present lack proper care: such a campaign would raise issues of a necessary expansion in the public welfare budget. For journalists too, who script and orchestrate the themes of a conservative populism, psychiatry's sins of omission and neglect make inferior copy and more muted headlines compared with its sins of commission in improper hospitalization and unjust confinement.

In the case of Conservative populist rhetoric, the psychiatrist is almost tailor-made to stand in lieu of the many forms of authority eligible as targets which a Right wing cannot too openly oppose. Organized Toryism, and even the moderate Centre of Labour and Social Democracy, is reluctant to criticize, en bloc, the police, the armed forces, the judiciary or the employing class. A Right-wing populism searching for targets of authority against whom it can claim to represent the unassuaged dissatisfactions of the little man', is precluded from identifying those power-structures which, like the army, the police or the entrepreneurial class, embody those national values of order and productivity which form a staple feature of other elements in their rhetoric. Psychiatrists, in contrast, cannot claim the exemption from criticism enjoyed by a chief constable, an admiral or a magnate: it may or may not be unfair to attack medical hegemony, but it is certainly not 'unpatriotic'.

Apart from these possibilities of bias which may inform a selective attention towards the misdoings and malfunctions of public psychiatry, Conservative populism has for some time been developing a marked preference for the reform and regulation of social ills by legal institutions of various sorts. The legal emphasis may be offered in an enhanced role for the judicial review of political decisions, advocated in different ways by Lord Hailsham and Lord Denning; or through the strengthening of a legal framework in such areas as industrial bargaining and trade-union power. The connection between this partiality for legal procedures and the fate of psychiatry may appear to be remote: but I have the sense that there is some lack of fit between legal and medical logic, for example, in the way they handle their conceptions of the rational individual. There is also some rivalry between those 
legal approaches which are out to check the State bureaucracy and those welfare-collectivist approaches which extend the role of bureaucratic agencies. There are in the present political context some particular reasons why the advance of legalistic thinking and enactment should bode ill for public psychiatry.

For modern populism, as a number of analysts have tried to show, ${ }^{3,4}$ delights in the creation for its public of new individually-framed identities, of an apparently radicalsounding nature, to counter the potential collective mobilization of organized masses and majorities. In more and more ways citizens are recruited and re-constituted individually, as consumers, as legal subjects, as litigants, being thus bestowed with a host of individual rights to offset the worsening situation of their more social entitlements. If you are harassed by your boss, messed up by your landlord, or deprived of work, housing or income, the remedy lies not in collective organization through direct-action methods or through pressure for reformed statutory provision, but rather in the adoption of an individual role as an aggrieved complainant. Who knows, your case may be taken up by the Ombudsman, or read out over That's Life by Esther Rantzen and her comforting fellow-announcers. And if you are a psychiatric patient bereft of opportunities for rehabilitation because there are no jobs, or of sheltered accommodation because a parsimonious local authority has curtailed its housing programme for the disabled-please, on that account, don't conclude that you have no rights. You have-in the shape of a multidisciplinary panel or Mental
Health Review Tribunal which will, with suitable advocacy, assure you of your freedom not to be medicated or kept on a hospital ward.

It would be wrong for me as a guest speaker from outside your profession to suggest the political strategies of alliance and pressure which psychiatrists should try to mount against this onslaught of scapegoating and irrelevant legalism by the new populists. But it is surely time for this wave of a manipulative and false populism to be met by a countertendency more genuinely populist, because expressing a people's ineluctable needs for communally-based provision and support in situations of distress. Those Right-wing ideologues who wish to 'roll back' the part played by the state in the development $o_{i}$ health and social services must now themselves be rolled back by the assertive defence of those popular conquests in the fields of welfare and care for the unfortunate, in which psychiatry can claim no small contribution of its own to the public good.

\section{REFERENCES}

'Sedgwick, P. (1982) Psycho Politics. London: Pluto.

${ }^{2}$ WEBB, A. \& Wistow, G. (1981) Whither State Welfare? Policy and Implementation in the Personal Social Services 1979-80. RIPA Studies No 8, London: Royal Institute of Public Administration.

${ }^{3}$ HaLL, S. (1979) The great moving right show. Marxism Today, January.

4Althusser, L. (1971) Lenin and Philosophy and Other Essays. London: New Left Books.

\section{Postgraduate Training in Behavioural Psychotherapy}

The Association of University Teachers of Psychiatry recognizes the recommendation of the Royal College of Psychaitrists (1971) that experience in behavioural psychotherapy should be an integral part of the training of psychiatrists. To help reduce the shortage of trainers in this field the AUTP, with the Institute of Psychiatry, runs a course to increase available training resources. This course is mainly intended for consultants and senior registrars and those of equivalent status, including specialist psychotherapists, but a limited number of other places may be available.

The course will begin with a two-day workshop on 28 and 29 September 1983. This will include the following components: theoretical background, demonstration of treatments and participant practice in small groups. After the workshop participants will be asked to undertake
Dehavioural treatment of their own patients in their own centres, and later also to supervise other trainees. Participants will be supervised in small groups at monthly intervals in half-day sessions over the following academic year.

The course is organized on lines which qualify for local funding assistance to applicants under the CPME Advanced Postgraduate Training Scheme to help senior medical staff develop special expertise in new areas. The cost of the combined workshop and monthly supervision over the following academic year would be $£ 190$.

Applicants should write, including a brief curriculum vitae, to Professor Isaac Marks at the Institute of Psychiatry, De Crespigny Park, Denmark Hill, London, SE5 8AF, where the course will be held. 